\title{
Obituaries
}

\section{John Cosh}

Rheumatologist who bridged the gaps between cardiology, rheumatology, and herbal medicine

John Cosh had many interests in clinical medicine but his main contributions were his long term studies of the effects of rheumatoid arthritis, co-discovery of the genes associated with rheumatoid arthritis, and his work on the benefits of herbal medicines.

In 1973, with R K Jacoby and M I Jayson, he published an 11 year follow-up of 100 patients newly diagnosed as having rheumatoid arthritis (BMJ 1973;2(5858): 96-100) and followed them for a further 30 years, showing that rheumatoid arthritis is a progressive disease impairing function for decades after onset. By 2004 eight of the sample were severely disabled with rheumatoid arthritis, three were less disabled, and only five had normal functioning. Of the 84 who died, median survival was reduced by 10 to 11 years, and the leading cause of death was heart disease.

In 1986 he published, with other rheumatologists, a study that showed the association of rheumatoid arthritis with several human lymphocyte antigens; the associations were stronger in patients with more advanced disease.

John Cosh had originally wanted to be a heart surgeon, but his interests shifted towards cardiology and then to the cardiological aspects of rheumatology. He was born in Bristol, the son of a pharmacist. From Bristol Grammar School he won a

\section{Advice}

We will be pleased to receive obituary notices of around 250 words. Pressure on space means that in most cases we will be able to publish only about 100 words in the printed journal, but we can run a fuller version on our website. We will take responsibility for shortening. We do not send proofs. Good quality, original photographs are welcome. Please give a contact telephone number and, where possible, supply the obituary on a disk or by email to obituaries@bmj.com If sending a picture electronically, please attach as a jpeg or a tiff rather than as part of a Word document. We need to know the year of birth and exact date of death of the deceased, and we prefer obituaries to state the cause of death. Please spell out abbreviations.

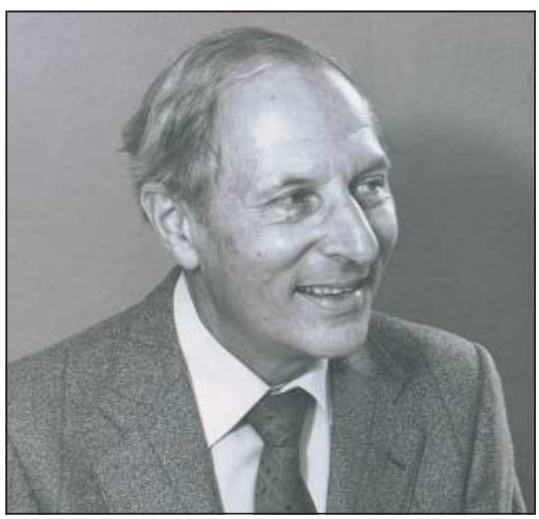

scholarship to St John's College, Cambridge, for his pre-clinical studies, and went to St Thomas's Hospital Medical School, London, for his clinical training. He qualified in 1940 and became a house physician at Lambeth Hospital, a satellite hospital of St Thomas's. From there he went to the Royal Hampshire County Hospital in Winchester.

He was called up into the Royal Navy Volunteer Reserve in 1942, serving on Arctic convoys to Murmansk and Archangel, was on the sidelines at the disastrous Dieppe landing, and took part in the landings in Italy in 1943 and 1944. He was mentioned in dispatches in 1945.

After the second world war he went to Bristol to train in cardiology and in 1948 was appointed registrar at Bristol Royal Infirmary, noted for studies in rheumatic heart disease. From 1951 to 1957 he was lecturer in medicine at Bristol University. During this time he published research on vibration sense, patent ductus arteriosus, paroxysmal nodal tachycardia, and primordial germ cells. Rheumatic fever was common at the time, and left many patients, most of them young, with damaged hearts.

In the late 1950s his research interest, and publications, shifted towards rheumatic heart disease and to the long term aspects of rheumatoid arthritis. Altogether he published 51 papers, many of major importance. With John Lever, a pathologist, he edited Rheumatic Diseases and the Heart (Springer Verlag, 1988).

In 1957 he became consultant physician for the Bath clinical area, practising cardiol- ogy at the Royal United Hospital and general medicine at the Royal National Hospital for Rheumatic Diseases. He felt he lacked expertise in rheumatic diseases and determined to teach himself. He attended ward rounds with the rheumatologist George Kersley, who appointed him, went to Hammersmith Hospital every week to attend Eric Bywaters' ward rounds, and visited Manchester, which had the United Kingdom's only professorial rheumatology unit. In 1959 he was awarded the Royal College of Physicians' Heberden medal for his research in rheumatology. He retired in 1982.

John Cosh was a holistic doctor in the true sense of the word, endlessly interested in and concerned about his patients and their lives, spending a long time on his ward rounds. He radiated gentleness, intelligence, courtesy, and warmth. Perhaps because of his patients' interest in alternative and complementary medicine, he became a keen supporter of the use of herbal medicine and its appropriate place in orthodox medicine.

This interest led him to become a consultant medical adviser for a manufacturer of herbal medicines, Gerard House, later Bio-Health Ltd, from 1984 until 1996 when he was 80. In 1997 he produced a handbook for patients, Arthritis and Rheumatism: The Sufferers' Guide, published by Amberwood Press, Bio-Health's publishing division.

$\mathrm{He}$ also became medical adviser and trainer at the Bristol Cancer Care Centre when he retired from the NHS, having been a lifelong friend of Dr Alec Forbes, the centre's first medical adviser. He taught on their courses, and contributed to a satellite centre in Cheltenham.

He retired to Totnes, to be near Dartington Hall, where he could indulge his love of music. Predeceased by his wife, Kate Jackson, he leaves two sons and a daughter. [CARoline Richmond]

John Arthur Cosh, consultant physician Bath 1957-82 (b 1915; q Cambridge/St Thomas's Hospital Medical School,London, 1940; MD, FRCP), d 6 October 2005. 


\section{Abraham ("Abs") Cohen}

Former general practitioner Liverpool (b west Hartlepool 1906; q Sheffield 1929; MSc), died on 6 February 2005 following a heart attack. After qualification Abs entered general practice in Liverpool in partnership with his brother. The one interruption in his more than 50 years of service was when he joined the Royal Army Medical Corps. In retirement he indulged his lifelong interest in mathematics and French, and dabbled in cooking (to his wife's dismay). Widowed in 2000, he leaves two sons and five grandchildren. [BERnARd CoHen, Howard Cohen]

\section{John Dermot Ainslie Common}

Former consultant ophthalmic surgeon North Staffordshire Hospital (b 1948; q Westminster Hospital, London, 1971; FRCOphth, FRCS), d 8 April 2005.

Dermot did a house job at the King Edward VII Hospital, Windsor, before working on oncocerciasis in Sierra Leone. In 1976 he was appointed as a registrar at the Western Ophthalmic Hospital. After his senior registrar years at Birmingham and Midland Eye Hospital he was appointed consultant ophthalmic surgeon at North Staffordshire Hospital in 1984. Dermot had an active interest in anterior segment surgery and trauma. He retired in 2003 owing to ill health, but continued to maintain his sporting interests despite an above elbow amputation of the left arm for sarcoma. [J T Gillow]

\section{James Antony Garrod}

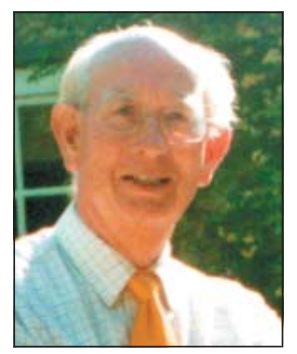

Former general practitioner Wendover, Aylesbury (b 1936; q St Bartholomew's Hospital, London, 1961), died on 4 July 2005 following a stroke. Tony Garrod did house jobs at Luton and Reading, where he met his future wife SallyAnne, then a student nurse. They settled into general practice in Wendover in 1963, where he was to spend his entire career, seeing the development of the practice from rooms in the partners' houses into purpose built premises, and through fundholding and practice based ancillary services. Following retirement he enjoyed tending their spectacular garden, hill walking, and overseas tours. He leaves Sally-Anne; four children; and two grandchildren. [TIM GARROD]
Mrinal Kanti Ghosh

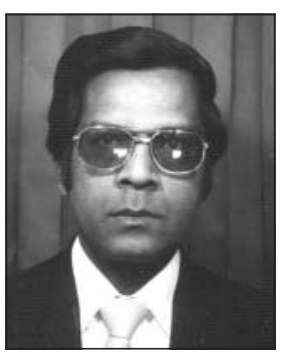

Consultant physician in medicine for the elderly Rotherham, South Yorkshire, 1976-2003 and honorary clinical lecturer in medicine for the elderly University of Sheffield (b Gurap, West Bengal, India, 1938; q Calcutta 1961;DTCD, FRCP,FRCP Glas), d 27 April 2005.

Mrinal began his career in geriatrics at Amersham, Buckinghamshire, in 1970. He then played a key role in developing geriatric services in South Yorkshire. Mrinal was a keen teacher and an avid reader. $\mathrm{He}$ leaves a wife, Roma, and two children. [Titus Fernando]

\section{John Haydn Martindale}

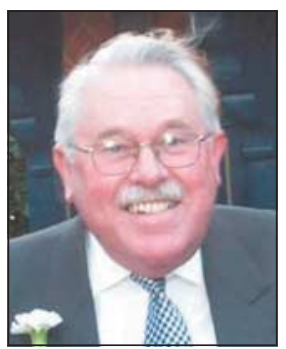

Consultant haematologist North Liverpool Hospitals 1975-97 (b Wigan 1936; q Liverpool 1960; FRCPath), died from prostate cancer on 30 July 2005.

John became a lecturer in bacteriology at the University of Liverpool in 1964 and then senior registrar in haematology at Liverpool Royal Infirmary. He was appointed full time consultant pathologist for North Liverpool and Southport group in 1965. In 1975 he became consultant pathologist (haematology) with Mersey Regional Health Authority with sessions at Walton, Fazackerley, and Waterloo hospitals. He was appointed honorary lecturer, University of Liverpool, in 1980. John was a keen dinghy sailor. He also had a passion for steam railways and did an engine driver's course in 1995. He leaves a wife, Annie; four children; and eight grandchildren. [E A MARTindale]

\section{Dipankar (“Dip") Sengupta}

General practitioner Eastfield, Scarborough, 1974-2005 (b India 1936; q Calcutta 1958; FRCS), died from cardiac failure on 28 July 2005. Dip came to England initially to become a surgeon. He worked in London, Glasgow, and Scarborough in both general and neurosurgery, publishing research work on cerebral blood flow. He entered general practice in 1974 and led the practice through immense changes with expansion in buildings, partners, list size, and activity. In 1996 he survived a dissecting thoracic aortic aneurysm and returned to work with renewed energy. Predeceased by his wife, he leaves a two children. [Philip Hughes]

\section{Kenneth Samuel Williamson}

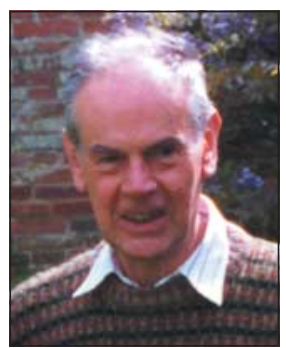

Former director of medical services ICI (b 1932; $q$ Manchester 1957; MSc, MD, FFOM), d 7 July 2005.

Ken started his career in the department of physiology at Manchester University as a Medical Research Council scholar. After coming into contact with the university department of occupational health to study the effects of shift working on adrenal function he moved into occupational medicine, but he never lost his academic approach and interest in physiology. He obtained a post in ICI working in the dyestuffs division, where there had long been an interest in chemical exposures leading to the development of bladder tumours. He stayed with ICI, eventually becoming the director of medical services in 1974. After retiring from ICI in 1985 he moved to Norwich, where he and his wife, June, established a small consultancy in occupational health. [W R LEE]

\section{Paul Francis Wright}

Former general practitioner Dorchester and general practice educator (b London 1945; $q$ The London Hospital 1973), died from mesothelioma on 29 May 2005.

Paul Wright first qualified in dentistry and then worked in child dental health and practice to finance his medical studies. After vocational training in Cirencester he moved to a two doctor practice in Dorchester and soon found himself senior partner. He became a GP trainer, and his interest and involvement in vocational training continued until his retirement, with posts as course organiser and associate adviser. Paul was secretary to the National Association of Course Organisers and was instrumental in setting up GP educators as a separate body from GP trainers. He leaves a wife, Jo, and four children. [CHARLES CAMPION-SMITH, Nick Panton, David Morgan] 